Artikel Penelitian

\title{
Introduksi Teknologi Pengering Tenaga Surya Untuk Meningkatkan Produktivitas Dan Pendapatan Usaha Kerupuk Ubi Di Kecamatan Kamang Magek Kabupaten Agam
}

\author{
Adli Havendri ${ }^{a}$, Dendi Adi Saputra ${ }^{a}$, Eka Satria $^{a}$, Syafi $^{\prime}{ }^{b}$ \\ ${ }^{a}$ Jurusan Teknik Mesin, Fakultas Teknik, Universitas Andalas, Kampus Limau Manis, Padang, 25163. Indonesia \\ ${ }^{b}$ Jurusan Teknik Elektro, Fakultas Teknik, Universitas Andalas, Kampus Limau Manis, Padang, 25163. Indonesia
}

INFORMASI ARTIKEL

\section{Sejarah Artikel:}

Diterima Redaksi: 13 Agustus 2018

Revisi Akhir: 24 September 2018

Diterbitkan Online: 29 Oktober 2018

\section{KATA KUNCI}

Cassava crackers

Productivity

Solar drying

community

KORESPONDENSI

E-mail: adlyhave@gmail.com

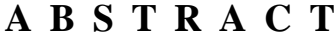

The micro, small and medium scale of industrial enterprises for cassava crackers is growing rapidly in Kamang Magek District of Agam Regency. Cassava crackers are the typical crackers which only find in the Agam Regency. The taste is crunchy and can be stored for a long time, making this cracker a special food souvenir. In the process of making, cassava is boiled and pounded so that it becomes pasta. Pasta will be formed and dried in the sun. The crackers that have been formed should be dried in a maximum of 1 day. Today, the makers of cassava crackers are still dependent on sunlight, so they often cannot meet market demand during the rainy season. Therefore, through the IbM (Ipteks bagi Masyarakat) program for the community funded by DIKTI, solar drying technology is introduced by using a type of solar tunnel. The result shows the drying time is 2 times faster than traditional drying process. Hopefully, this technology can help the community of the cassava crackers maker to increase their productivity.
\end{abstract}

\section{PENDAHULUAN}

Ubi kayu (Manihot utilissima) merupakan tanaman perdu yang banyak ditemui di daerah tropik dan subtropik. Sumatera Barat merupakan daerah yang memiliki potensi yang cukup besar dalam produksi ubi kayu. Pada tahun 2011 produksinya mencapai hampir 192 ribu ton dengan total lahan produksi seluas hampir 5600 ha (Anonim, 2013). Kabupaten Agam merupakan salah satu daerah di Sumatera Barat yang memiliki potensi yang besar dalam pengolahan makanan berbahan dasar singkong.

Salah satu usaha pengolahan ubi kayu yang banyak dilakukan adalah usaha kerupuk ubi. Selain dipasarkan secara lokal, kerupuk ubi tersebut juga telah dipromosikan sebagai oleh-oleh makanan khas Sumatera Barat. Pada umumnya usaha kerupuk ubi dikelola oleh industri rumah tangga (IRT). Satu IRT minimal mampu menghasilkan produk kerupuk ubi mentah hingga $50 \mathrm{~kg} / \mathrm{hari}$ tergantung dengan teknologi dan kapasitas produksi yang tersedia.

\section{Mitra Pengabdian (IRT Erna)}

Industri Rumah Tangga (IRT) Erna merupakan usaha kecil menengah yang bergerak dibidang usaha kerupuk ubi. IRT Erna terletak di Jorong Limau Kambing Nagari Kamang Mudik, Kecamatan Kamang Magek Kab. Agam Sumatera 
Barat dengan jarak sekitar $110 \mathrm{~km}$ dari Ibukota Provinsi Sumatera Barat (Padang). IRT ini bergerak dalam bidang pengolahan, pembuatan dan penjualan kerupuk ubi dengan nama "Kerupuk Ubi Erna". Pengolahan ubi kayu menjadi kerupuk ubi mentah dilakukan melalui beberapa tahapan proses, yaitu pengupasan kulit, perebusan, penumbukan untuk menghasilkan pasta, pengepresan pasta untuk mendapatkan lembaran pasta dengan ketebalan tertentu, pencetakan, dan pengeringan.

Salah satu proses yang menentukan kualitas dan nilai jual kerupuk ubi baik dipasaran adalah kerupuk ubi yang kering melalui proses pengeringan dengan panas matahari selama $5-6$ jam (Erna, 2016). Keadaan ini dapat dicapai jika panas matahari yang diterima konstan dan cuaca cerah tanpa berawan. Namun, jika cuaca mendung bahkan hujan akan menyebabkan proses pengeringan terhambat dan proses produksi kerupuk ubi terhenti. Kerupuk ubi yang dikeringkan lebih dari 6 jam, akan membuat tesktur dan warna kerupuk ubi berubah (Gambar 1). Selain itu, kerupuk ubi yang kurang kering akan sulit mekar saat digoreng dan kurang renyah bila dimakan. Kondisi kerupuk seperti ini dihindari oleh pembuat dan pembeli kerupuk ubi. Kerupuk akan menjadi keras dan volume per satuan kerupuk menjadi kecil serta massa kerupuk menjadi lebih besar sehingga akan merugikan pembeli (customer).

Saat ini, IRT Erna masih menggunakan metode pengeringan konvensional berupa pengeringan melalui panas matahari. Hal ini akan menyebabkan ketergantungan produksi kerupuk ubi terhadap perubahan cuaca. Ketersediaan teknologi pengering dengan menggunakan panas buatan sebagai pengganti panas matahari belum mampu menjadi solusi pengering kerupuk ubi bagi IRT pengolah kerupuk ubi di Sumatera Barat. Kerupuk ubi yang dikeringkan secara paksa akan menyebabkan ketidakmerataan suhu pengeringan pada produk kerupuk ubi. Dengan kondisi tersebut, IRT Erna sangat mengantungkan proses produksinya terhadap cuaca sehingga proses produksi dan pemasaran menjadi tidak bisa dilakukan secara berkelanjutan. Kondisi ini akan sangat merugikan IRT Erna karena akan membuat pelanggan (toko besar) mencari pasokan baru.

\section{METODOLOGI}

\subsection{Penentuan permasalahan mitra}

Berdasarkan analisa situasi pada mitra yang sudah dilakukan melalui survei pendahuluan ke IRT Erna yang berlokasi di Kabupaten Agam dapat diidentifikasi dan dirumuskan permasalahan yang dihadapi mitra dalam produksi usaha kerupuk ubi sebagai berikut:

a. Salah satu rancangan komponen yang dibutuhkan dalam usaha produksi kerupuk ubi adalah peralatan pengering, roll press dan cetakan mekanis. Peralatan pengering, roll press dan cetakan mekanis merupakan alat bantu utama untuk melakukan proses pencetakan pasta ubi. Dari pengalaman mitra, proses pengepresan, pencetakan membutuhkan operator khusus yang melakukan proses produksi kerupuk ubi. Operator yang belum mahir akan menyebabkan terbuangnya material pasta ubi yang akan dicetak sehingga peningkatan produktivitas produksi sulit dilakukan. Sedangkan untuk proses pengeringan, kedua mitra sangat bergantung pada cuaca matahari.

b. Cetakan manual menggunakan gelas/ kalengsusu bekas dengan 1 proses cetakan menghasilkan 1 cetakan. Konsekuensinya adalah waktu yang dibutuhkan untuk pencetakan menjadi lama.

\subsection{Metode pendekatan pemecahan masalah}

Model pendekatan pemecahan masalah dalam program IbM ini menggunakan pendekatan problem solving yang meliputi analisa situasi, perumusan masalah secara spesifik, penentuan prioritas masalah, penentuan tujuan, memilih alternatif terbaik, menguraikan alternatif terbaik menjadi rencana operasional dan melaksanakan rencana kegiatan.

\subsection{Rencana kegiatan}

Rencana kegiatan yang akan dilakukan adalah sebagai berikut: 
1) Identifikasi masalah (telah dilakukan)

Identifikasi masalah dilakukan dengan survei lapangan ke lokasi mitra. Dalam survei ini dilakukan peninjauan kembali proses produksi kerupuk ubi, mulai dari pengolahan bahan baku sampai menjadi kerupuk ubi. Kegiatan wawancara dengan mitra dilakukan untuk mengetahui permasalahan dan keinginan mitra dalam pengembangan usaha kerupuk ubi.

\section{2) Peningkatan produktivitas}

Peningkatan produktivitas dilakukan dengan rancang bangun peralatan pengering tipe efek rumah kaca, mesin roll press dan cetakan mekanis pasta ubi. Untuk itu, terlebih dahulu dilakukan perancangan pengering yang disesuaikan dengan target kapasitas produksi Mitra. Setelah dihasilkan sebuah konsep rancangan dan gambar detail dari peralatan, maka tahap berikutnya adalah proses manufaktur peralatan pengering dan mesin tersebut di bengkel manufaktur terdekat. Pemilihan bengkel yang sedekat mungkin dengan lokasi mitra adalah untuk memudahkan perawatan atau perbaikan bila terjadi kerusakan.

\subsubsection{Perancangan perangkat}

Dalam perancangan perangkat peralatan pengering kerupuk ubi, ditempuh langkah-langkah berikut seperti terlihat pada Gambar 1. (eggert, 2005).

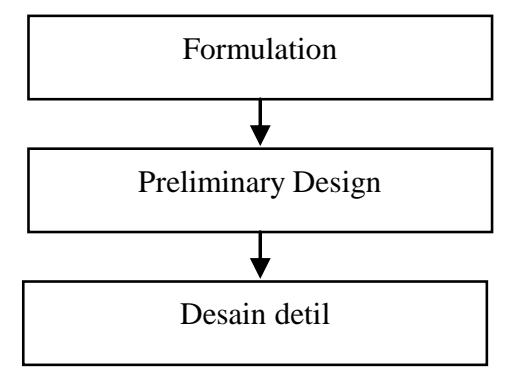

Gambar 1. Tahapan perancangan

\subsubsection{Pembuatan (proses produksi)}

Proses produksi dilakukan di bengkel/workshop yang dekat dengan lokasi mitra yang mampu melakukan proses fabrikasi, seperti pengelasan dan proses permesinan.

\subsubsection{Introduksi alat ke mitra dan evaluasi}

Peralatan yang telah dibuat, disosialisasikan kepada mitra dengan tujuan untuk mengenalkan dan memberikan informasi mengenai cara penggunaan alat dan standar operasional prosedur dari alat yang dibuat. Evaluasi perangkat dilakukan untuk mengukur performansi dari perangkat yang dibuat. Penyusunan SOP produksi dan proses produksi usaha kerupuk ubi untuk masing-masing mitra.

\subsection{Partisipasi mitra}

Partisipasi mitra dalam pelaksanaan program adalah menyediakan lokasi dan pekerja untuk turut serta dalam proses perencanaan hingga uji coba prototipe. Masing-masing mitra menyediakan bahan mentah berupa ubi kayu dan peralatan pendukung lainnya seperti tempat pembersihan, perebusan dan pengeringan ubi.

\section{HASIL DAN PEMBAHASAN}

\subsection{Survey Kebutuhan dan Klarifikasi Konsep Disain Rumah Pengering}

Tahapan ini dilakukan untuk menyesuaikan peralatan teknologi yang ingin diterapkembangkan dengan kebutuhan mitra saat ini. Survey kebutuhan dan klarifikasi konsep disain teknologi yang dilakukan adalah teknologi pengering dan mesin penggiling yang dilengkapi dengan pencetak mekanis. Tingginya kelembaban yang ada dilokasi mitra 1 akan mempengaruhi kinerja dan rumah pengering yang dirancang. Melihat kondisi mitra 1 tersebut, maka konsep rumah pengering dengan tipe tunnel dipilih untuk dibangun melalui program IbM tahun 2017. Pada Gambar 2 terlihat disain akhir rumah pengering tipe tunnel yang akan dibangun dilokasi mitra 1 


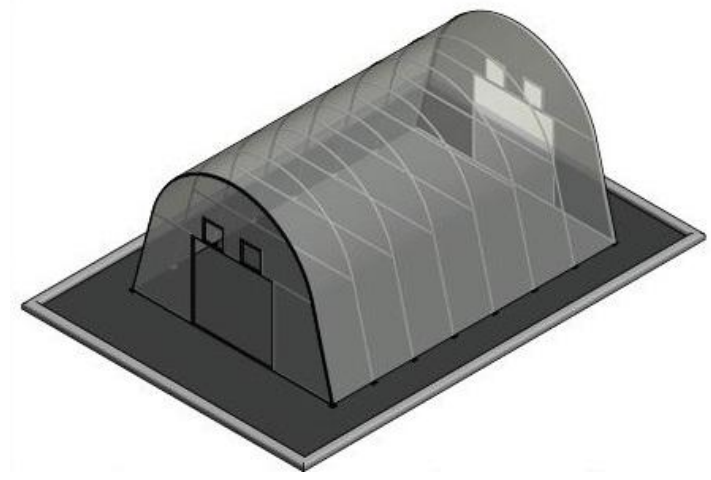

Gambar 2. Disain akhir rumah pengering

\subsection{Proses produksi rumah pengering kerupuk}

Pada tahap ini dilakukanlah proses produksi rumah pengering kerupuk ubi. Pembangunan rumah pengering didirikan diatas tanah milik mitra 1 dengan luas tanah $6 \times 8 \mathrm{~m}$. Luas rumah pengering

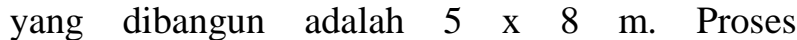
pembangunan rumah pengering didahului dengan pengecoran lantai dan selanjutnya pembuatan kerangka rumah pengering berbahan baku besi stalbus. Kerangka rumah pengering dibuat dengan konsep portabel, dimana kerangka dapat dibongkar pasang dengan mudah.

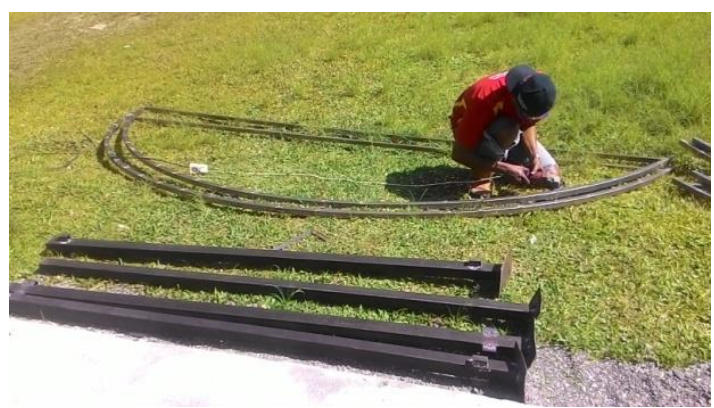

Gambar 3. Kerangka atap rumah pengering

Kerangka yang telah dibuat akan dirakit menjadi sebuah rumah pengering. Proses perakitan dilakukan dengan proses baut, las dan paku keling. Rumah pengering yang telah dirakit dapat dilihat pada Gambar 4.

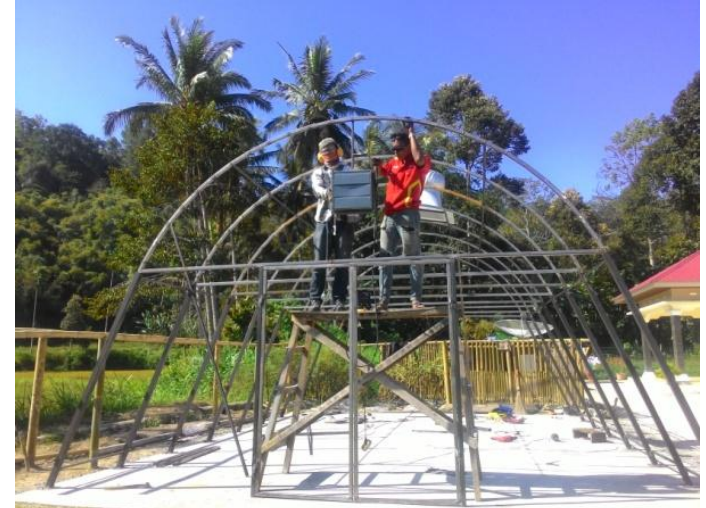

Gambar 4. Rumah pengering yang telah dirakit

Rumah pengering yang telah dirakit selanjutnya dilapisi dengan plastik UV dan diinstalasi peralatan kontrol temperatur, kelembaban dan sistem sel surya sebagai sumber energi. Pada Gambar 5 terlihat rumah pengering telah dilapisi plastik UV dan dilengkapi dengan peralatan kontrol temperatur dan kelembaban serta sel surya sebagai sumber energi rumah pengering.

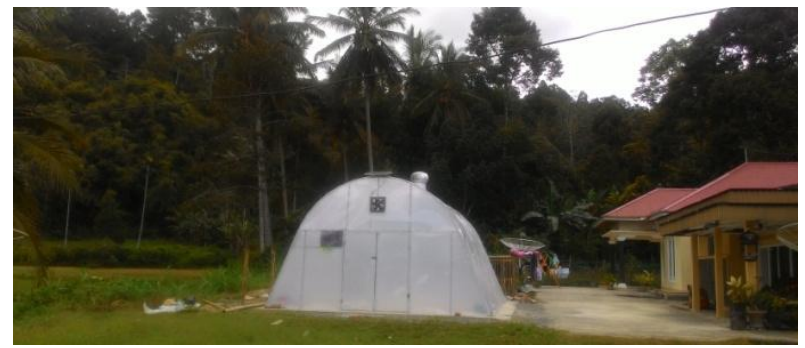

Gambar 5. Rumah pengering kerupuk ubi tipe solar tunner

\subsection{Prinsip kerja dan uji fungsional}

Rumah pengering tenaga surya yang dibangun dilengkapi peralatan kontrol temperatur dan kelembaban yang dioperasikan secara otomatis. Exhaust fan akan otomatis beroperasi ketika temperatur melewati $30^{\circ} \mathrm{C}$ dan kelembaban diatas $50 \%$. Uji fungsional dilakukan untuk mengetahui fungsionalitas dari rumah pengering serta peralatan yang terpasang didalamnya. Kerupuk ubi yang masih lembab dikeringkan didalam dan diluar rumah pengering. Kapasitas rumah pengering yang dibangun mampu mengeringkan 26 rak pengering yang disusun secara paralel didalam rumah pengering. Masing-masing kerupuk ubi dihitung waktu pengeringannya pada kondisi cuaca yang sama antara di dalam dan di luar rumah pengering. 
Dari hasil pengujian fungsional yang dilakukan, kerupuk ubi yang dikeringkan di dalam rumah pengering bisa dikeringkan 2 kali lebih cepat dibanding di luar ruangan.

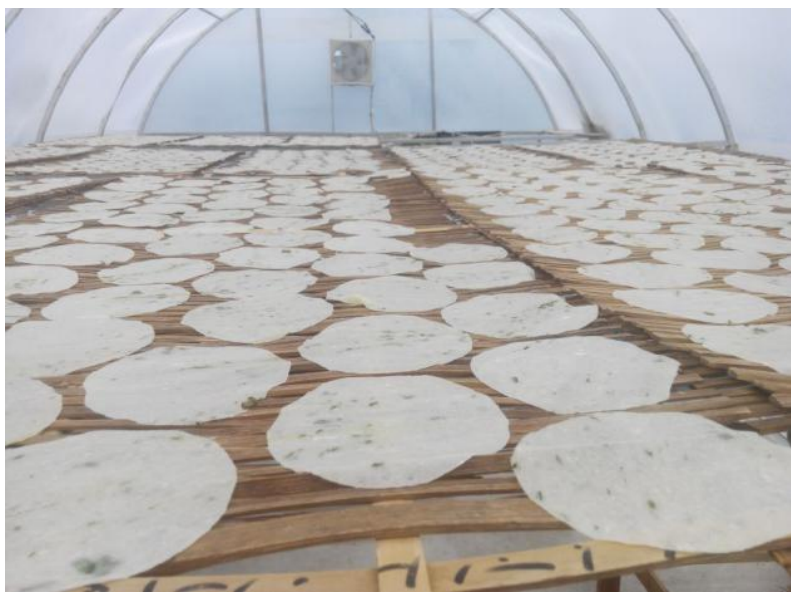

Gambar 6. Kapasitas rumah pengering sebanyak $26 \mathrm{rak}$

Lamanya waktu pengering pada metode konvensional menyebabkan terjadinya perubahan warna pada hasil akhir kerupuk ubi yang dikeringkan. Hal ini menyebabkan kerugian karena selain mengakibatkan kerupuk tidak renyah juga berakibat turunnya animo masyarakat untuk membeli kerup. Pada Gambar 7 b dapat dilihat bahwa pengeringan dengan menggunakan teknologi pengering tenaga surya yang telah diintroduksikan, menghasilkan tekstur warna kerupuk ubi yang putih dan bersih dari kotoran maupun debu.

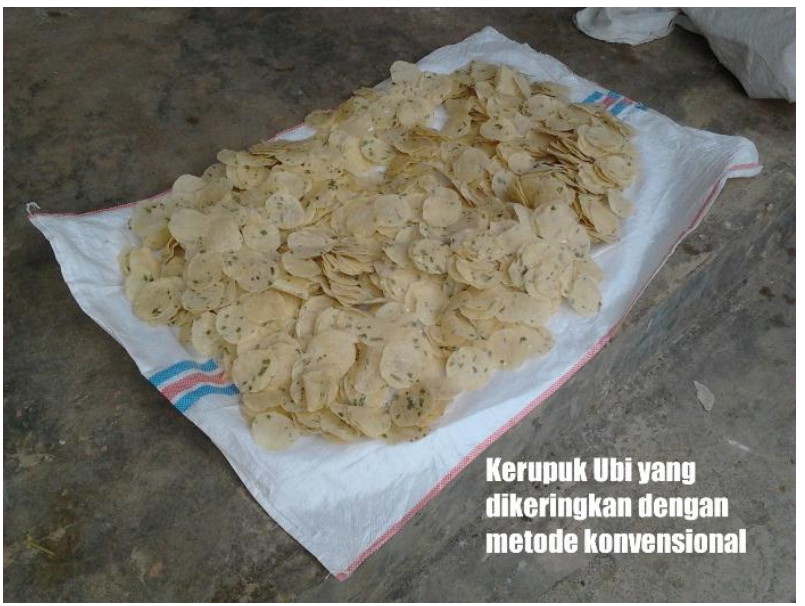

(a)

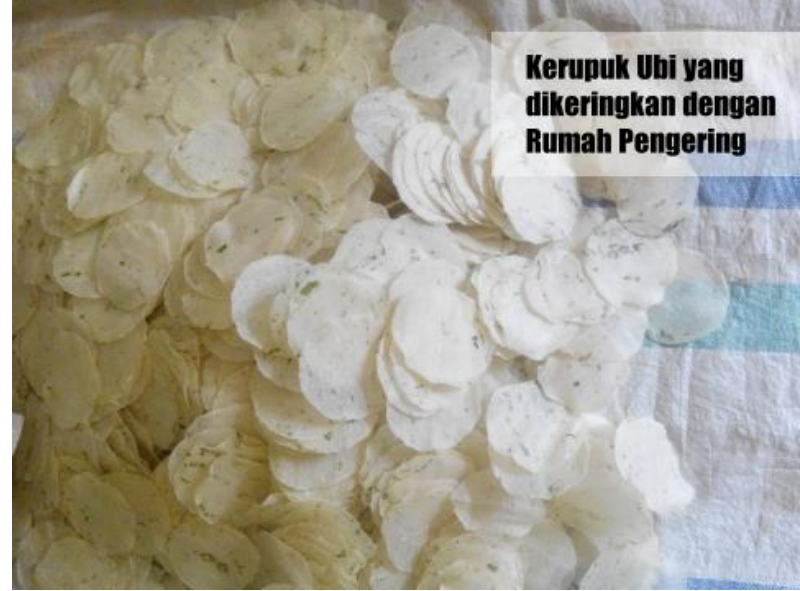

(b)

Gambar 7. Visualisasi perbedaan warna kerupuk ubi, a. Dengan menggunakan pengeringan tradisional (cahaya matahari), b. Menggunakan solar tunnel drying

\section{KESIMPULAN DAN SARAN}

Telah diterapkannya teknologi pengering pada kegiatan pengabdian masyarakat yang dilakukan pada industri kerupuk ubi skala rumah tangga di Kabupaten Agam Sumatera Barat. Dari kegiatan pengabdian masyarakat ini dapat disimpulkan bahwa teknologi pengering yang digunakan oleh IRT Erna mampu meningkatkan produktivitas kerupuk ubi hingga 2 (dua) kali lipat yaitu 1.000 bungkus per bulan dan telah dapat memperkerjakan tenaga ibu rumah tangga yang lain sebanyak 2 orang diluar anggota keluarga.

\section{UCAPAN TERIMA KASIH}

Terima kasih kepada Kementerian Riset dan Pendidikan Tinggi (Kemristekdikti) yang telah mendanai kegiatan pengabdian ini melalui Skim Ipteks Bagi Masyarakat Pendanaan Tahun 2017.

\section{DAFTAR PUSTAKA}

Anonim,2013, http://regionalinvestment.bkpm.go.id/newsipid/id/c om modityarea.php?ic=2581\&ia $=13$ 
N. Cross, Engineering Design Methods, 2nd Ed., John wiley \& Sons, Chichester, England, 1994.

D. Yelmi, "Pelaku usaha kerupuk ubi. Jorong Koto Kaciak Magek, Kec. Kamang Magek, Kab. Agam," komunikasi pribadi, 2013.
R.J, Eggert, Engineering Design, Pearson Prentice Hall, Upper Saddle River, new Jersey, 2005.

http://agamkab.go.id/?agam=pertanian, diakses pada tanggal 18 April 2014 